\title{
Epistemo-political decolonization: reflections from the Brazilian and Bolivian cases towards an intercultural politics
}

\author{
Keywords: Quilombola, mythical, territorial, dilma's \\ government, social anthropology
}

\section{Introduction}

The proposal of this article is to create a comparative reflection based on our fieldwork with the quilombola communities in Brazil and our research effort on the constituent process in Bolivia (between 2006 and 2009). Firstly, we briefly describe the contexts of recognition of quilombola communities in Brazil and the rights of indigenous peoples in Bolivia. Next, we address the dilemmas and limits of this recognition that "runs into" the limits of the coloniality of power. ${ }^{1}$ The approach, therefore, deals here with an absolutely incomplete process with regard to intercultural relations, ${ }^{2}$ in which the root of indigenous and quilombola knowledge is not taken to its ultimate consequences.

The guiding question of the present reflection revolves around an agonistic relationship between the legal, administrative construction spaces and the mythical, territorial, symbolic universes of indigenous groups (Bolivia) and quilombola groups (Brazil). The pertinence of such comparative potential is justified here, in that the two experiences seem to reveal different potentials of dialogue between these dimensions. Our major undertaking here is to demonstrate both forward and backward movement in both cases. Next, it is necessary to try to understand to what extent the two social complexes aimed at a not simple task of recognition of their territories and social practices. According to the elements here concerning the quilombola question, they are the result of our fieldwork under the conditions of anthropologists experts appointed by INCRA (National Institute of Colonization and Agrarian Reform) to construct anthropological reports identifying these communities. Between 2009 and 2014 we had the challenge of participating in the construction of anthropological reports in the state of Sergipe. ${ }^{1}$ The fieldwork carried out with the communities of Caraíbas (Canhoba municipality of Canhoba), Ladeiras (municipality of Japoatã) and Forte (municipality of Cumbe) is taken as the basis for the discussion of the existing disjunctions between the mythological-territorial structure and the legal administrative emplacement destined to such communities. In this sense, the objective here is to deal with the not uncommon difficulty of technical operators in the perception of the native quilombola language. The historical, political and social genesis about the quilombola case, presented in the present manuscript, are built on the basis of the historiographical and anthropological literature specialized. ${ }^{3-7}$

The main sources for our research on the Bolivian process were the ethnographic and theoretical work produced during the Constitutional Assembly by Bolivian and other Latin American authors, such as Salvador Schavelzon ${ }^{8-10}$ and Luis Tapia, ${ }^{11}$ among others in addition to

${ }^{1}$ Part of this experience resulted in the PhD thesis of Cristian Salaini, author of this writing. The title of the thesis is "The Technical Report Window: variability, creativity and social recognition in contexts of anthropological expertise". Program of Social Anthropology of the University of Rio Grande do Sul (2012).

\author{
Volume 3 Issue I - 2018

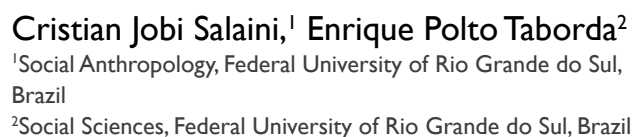

Correspondence: Cristian Jobi Salaini, Social Anthropology, Federal University of Rio Grande do Sul, Brazil, Email salaini@gmail.com

Received: December 15, 2017| Published: February 06, 2018

a brief period of fieldwork in the summer of 2017, where due to the temporal distance, the events studied could be discussed in perspective with some of the actors involved in La Paz and Cochabamba.

\section{In brazil}

The article 68 of the Brazilian Federal Constitution of 1988 and its infra-constitutional apparatus created, from the legal point of view, a revolution regarding the processes of recognition of quilombola communities in Brazil. These social groups which through a criterion of ethnic self-attribution are called quilombolas, have territorial cultural and symbolic ties with the Brazilian slave-owning past. The favorable context, as a result of the political battles of the preconstitutional scenario of 1988, allowed a diversity of experiences of black collectivities in Brazil to be recognized through the legal category "remnants of quilombo". ${ }^{3-7,12-17}$

The anthropological literature related to the subject points to the deconstruction of the "frozen" and colonial - versions of the quilombo concept that would directly relate it to the notions of escape and isolation, placing it physically and symbolically outside the domain of civilization. Almeida ${ }^{4}$ demonstrates how different authors have taken as reference a legal-formal notion of a quilombo from the colonial period, such as that formulated as a "response to the King of Portugal" resulting from a consultation with the Overseas Council of 1740 . According to this current version, the quilombo would be defined by fundamental criteria that involve escape, a minimal amount of "escapees", the idea of a geographic isolation (outside of civilization, in a space of nature), the existence of a "ranch" and "pylons". ${ }^{4}$

This notion that takes isolation as a central point has resulted in the interpretation of an idyllic quilombo and outside of the relations of the production and market, resulting "another type of division, that describes the quilombos marginally, outside the physical domain of the plantations". ${ }^{4}$ The reflection in the semantic field of the quilombo concept demonstrates a series of associative possibilities still in the pre-abolition time that were not incorporated in the formal definitions about the quilombo, already promoting a discrepancy between the "practical situations" and the legal-formal definitions of the colonial 
environment. ${ }^{4}$ Extensive to this element, there is a whole set of reflections promoted by historiography on the subject that seeks to demonstrate how the black groups could establish a position of "farm fund", producing relations of continuity with the slave center, including commercial relations and proximity to farms, towns and cities. ${ }^{18}$

The quilombo, from the theoretical point of view, presents a genealogy those results in different interpretive possibilities. In a first analytical plane, we have the versions that place the quilombo as reproductions of "African models", a form of cultural resistance that would promote direct relations with Africa. In a second plan, we have a classist interpretation of the quilombo of Palmares, which is seen as a focus of popular resistance in relation to the structures of domination. A third plan for the resemantization of quilombos found in the black movement, which places it as an icon of the black resistance. The behind-the-scenes discussions about the Article 68 of the ADCT (Act of Transitional Constitutional Provisions) of the Brazilian Constitution reveal at least two positions outlined: one directly linked to militancy, which understands the quilombo as a fundamental point of resistance of the black culture and another, directly related to the demands for land access and land reform. ${ }^{19}$

Therefore, it is necessary to emphasize the tensions between the juridical/administrative field and the space of practical quilombolas experiences. The quilombos present themselves as spaces that have always been in front of negotiation processes with the prevailing orders. It is based on the general premise that article 68 of the Brazilian Federal Constitution appears as a further legal-political framework that articulates with the historicity of these groups (something that does not minimize the immense political gain derived from this constitutional innovation). In this sense, "today's quilombos" do not present themselves as a reminiscence or survival of the past On the contrary, the position from which the quilombos emerge suggests a variety of cases that produce a minimal arrangement for their definition. The quilombo definition process is directly related to societal schemes that have remained alive in historical and social contexts, fighting for their physical and symbolic survival, despite the ever present categorical lag produced by external classifiers.

It is mainly the result of processes of confrontation, not of utopian and depoliticized places. Here would be the position from where the quilombos emerge. In short, it is an impropriety to deal with this process as "survival", as "remnant", as leftover or residue, because it suggests to be just the opposite: it is what has achieved a reproduction, is that it has remained more preserved, is what maintained the natural framework in better conditions of use and is what guaranteed these social groups conditions to live independently of the favors and benefits of the State. ${ }^{4}$

To present, however, the quilombo as an object in dispute and submitted to semantic enlargements due to the empirical challenges presented by concrete cases does not result in an emptying of its category and its potential as a signifier. The category itself, endowed with historicity, is the result of a series of crossroads between social movements, legal and administrative field and the anthropological discipline itself. The issue here revolves around a creative dialogue between the "native world" and the public reconnaissance operations that always present a kind of conceptual gap. This element always entails a new fixation of the nominative categories of the State, which do not account for the processes presented through the "quilombola social facts".
The compromise established between anthropological discourse and the legal and administrative discourse in this nomination process costs to the anthropologists direct collaboration in the state partition practices by establishing a new classificatory category, whose function was, again, to reduce the variety of social experiences and representations to a legal-administrative model of designation. ${ }^{19}$ In this sense, there is a gradual displacement in the meaning of quilombo shared by the black social movement of the main cities, to a sense given by the movements of rural communities that focused on the struggle for land. This articulation between urban and rural movements, which at first were located in a majority way in the states of Pará and Maranhão, created the necessary conditions for the construction of a Joint of Remnants of Quilombos in a national dimension. It should be emphasized the existence of several groups and social movements concerned with the discussion of rural black communities and quilombola communities. The first great meeting of the rural black communities occurred in 1985 in Pará through the Encontros de Raízes Negras. In Maranhão, the Center of Black Culture began to realize the situation of the black communities of the state in 1986, resulting in I Encontro das comunidades negras do Maranhão (First Meeting of the black communities of Maranho).

From these initiatives comes the project Vida de Negro, which starts to map the uses, the forms of possessions and the oral memory of the black groups. It is worth noting that despite all the initiatives of the popular field, these are carried out independently of the parliamentary proposers of Article 68, revealing a timid dialogue among these fields, despite the fundamental importance of these movements in the process. In this sense, the discussion no longer has a polarized nature between a cultural dimension and a peasant dimension of the agenda; it can be seen that the cultural grammar of these groups cannot be dissociated from their territorial matrices. In general terms, this was the discussion that culminated in the proposition of Article 68 of the Brazilian Federal Constitution. We can say that the quilombola current situation in Brazil is due to the articulation between social movement, the struggle for the concept of quilombo in the historiographic field and the participation of the anthropologists (from the 90s) in the condition of experts of reports and anthropological reports destined to these communities. The figure of ABA (Brazilian Association of Anthropology) appears as a fundamental actor in this direction, through the incorporation of concepts of ethnicity to the technical and legal discussion. ${ }^{19}$

The election of Luiz Inácio Lula da Silva represented, for the quilombolas and social agents involved with the ethnic cause, the perspective of a government that would end the neoliberal cycle, as well as the possibility of attending sectors of society that have always been excluded from the process of growth. The government's dialogue with the social movements immediately led to the repeal of Decree 3912/01 of the government of Fernando Henrique Cardoso, which was already the subject of direct unconstitutional action by the Federal Public Ministry and organizations that support the quilombola cause. After Lula's inauguration, workshops were organized with quilombolas, researchers and government sectors to create a tool that would help the process of recognition of quilombola rights. The summary of the discussions was sent to the presidency and the result came on November 20, 2003, with the sanction of Decree 4887/03, which defines the attributions of government bodies in relation to the demarcation and delimitation of quilombola territories. ${ }^{20}$

Conservative sectors in the Congress and vehicles of the mainstream media began a defamatory campaign and, in this context, the Order $n^{\circ}$ 
98 of the Palmares Cultural Foundation appeared, which tried to stop the initiative of the communities to declare themselves quilombolas as foreseen in ILO Convention 169. Then, the former PFL (Partido da Frente Liberal), now DEM (Democratas), requested a lawsuit of unconstitutionality of Decree $4887 / 03$. The pressure began to be felt. The normative instructions of the INCRA were altered, in recourse of the conservative sectors before the impossibility of revoking of the Decree 4.887. In 2008, the Central Única dos Trabalhadores Nacional denounced the Brazilian government for breaching ILO Convention 169 (right to self-determination), due to the low effectiveness of the implementation of access to land by quilombolas. The government then launched, with wide dissemination, the Brasil Quilombola Program, which provided resources for application in the communities. In the course of time, however, it was found to be of very low effectiveness, without the communities actually being able to benefit.

The government of Luiz Inácio Lula da Silva (2003-2010), which was based on a context of social inclusion policies at different levels of Brazilian society, gave way to the "developmentalist" rhetoric in the Dilma government (2011-2016) which sought to consolidate the image of Brazil as a global power. This rhetoric, however, generated a kind of emptying of issues regarding the recognition and rights of quilombola communities in the country, opening the way for the return of conservative sectors of Brazilian society to positions of decision, generating the discontent of those who fight for of ethnic rights in the country. ${ }^{20}$

In Dilma's government (2011-2016), there was a distancing of the social movements and a resurgence of the relations. The celebrated stance of a "technical" management masked the approach with sectors of the agribusiness that, until then, did not have their interests contemplated by the government. This orientation allowed the realignment and strengthening of the ruralist group, paralyzing the actions of the government and allowing clashes with the quilombolas to happen again from north to south of the country. The Normative Instruction No. 57 appeared in 2009. Administrative procedures introduced requirements that were weird to anthropological discipline and revealed a valuation of parameters considered and seen as more "objective", but which sought to create a fixity to complex forms that are part of the experiences in the different groups studied. The article 10 of the normative instruction brings, among other things, the basis of RTID (Technical Report of Identification and Delimitation) based on 'objective elements' in what it refers to anthropological and ethnographic information. It should be noted that the quilombola movement interprets the changes presented in the NI 57 as a retrocession to the political demands of this sector of Brazilian society. ${ }^{21}$

The construction of such Normative Instruction is understood as the result of pressures from landowners, military bodies and sectors of the federal parliament, such as that produced in 2004 by the DEM (Democratas and former PFL) with the intention of demanding an unconstitutionality action to Decree 4.887 / 03. From this conjuncture, there is a growing distrust of quilombola identities, as well as of their territories and their ancestral practices. The very sectors responsible for the recognition of such groups often come to wonder about the importance of the mythological aspects that compose the cosmos of the native groups. Therefore, according to this logic coming "from above", the questioning is directed to the supporting character of narratives and native myths: "would these data be serious or even important, operators wonder? After all, we need technical and objective data").
It prevails a vision of territory as a space occupied only by dwellings and not a comprehensive interpretation that stresses the classical dichotomies between nature and culture or even mythos and logos. It should be emphasized that the field experience reveals the incredible possibility of perceiving a true technological body constituted within such communities. Access to mythology and quilombola corporality is not reduced, according to local logics, to a simple resumption of past events. What is at stake is the creative possibility of collective resistance that reinvigorates practices of territorial management and belonging. I refer specifically to the active medical catalog of these groups, kinship technologies, practical notions of "living well" and territorial management. ${ }^{21}$ However, such practices are not always accessible at first sight to an "unsuspecting reader".

In our fieldwork with the quilombola communities of the state of Sergipe, we were able to get in touch with the complex mythological logic that makes up the historical path of these social groups. The myth, above all, presents itself as an expressive dimension of the group's territoriality. The myth translates as a possible metaphor that groups different historical layers, serving as a kind of viewer of symbolicterritorial boundaries of the group in question. The apprehension of the mythical dimension of the group refers to a series of past events that help to understand the logic of occupation of the group. They also express notions of danger at the territorial borders. Certain contours about the group's bond with an expressive cosmological dimension of its contact with nature, in a very intense way, are part of the group's interpretive arsenal about its experience in space.

Take the case of the Caipora's myth. The figure of Caipora is known from Brazilian folkloric stuff. According to recurrent narrative, this creature is a type of "enchanted", a supernatural force that, not infrequently, confuses the more unsuspecting hunters. It is possible to "feel" that the Caipora is present through its long whistles that indicate the need for some care when entering the woods. It has the power to confuse the hunter, making him lose the notion of geographic reference, "inverting" the north and the south, the east and the west, which, were it not for the Caipora, would be something quite ordinary and commonplace to the hunter accustomed to space.

Out of the case of these most famous enchantments, how does the process of disenchantment take place? As I said before, the enchanted are people who, on the contrary of the saints, did not die, but were enchanted. In this process they do not interfere with moral merit, as in the case of the saints, who are often thought as persons who have done good while living. People are touched because they are attracted by others to the "enchantment," their home address. The enchantment lies "in the background", usually in the rivers and lakes, in underground or underwater cities. In order for someone to be taken to the bottom, by an enchanted one, it must be "liked" by the person for some reason. It is common to think that if someone is taken by some enchanted person to visit the enchantment, he should avoid eating the things offered to him, otherwise he will be enchanted and then he can no longer live in the surface world, like other human beings. There is also the idea that the great pajés are taken by the enchanted ones to the bottom, where they learn their art; but in this case, they re-emerge as shamans on the surface in order to practice pajelance. It is very strong, in the Salgado region, the idea of these entities as enchanted or critters of the background. But it is not absent the constant reference to the "forest's enchantments", which are only two: Anhanga and Curupira. It is, in this case, dangerous beings, who can provoke evil-eye on people, or "mundialas", that is, make them lose themselves in the woods. It happens with hunters who commit "abuses," especially those who have the habit of persistently hunting one type of game. ${ }^{22}$ 
It seems self-evident that this myth talks about perspectives on nature, serving as a kind of taboo and limits to the one that goes into the woods. What matters here, however, is to refer to the space that this myth occupies, in the quilombo of Caraíbas, as the vehicle of identity. The myth, however, is part of a much larger imaginary universe that is part of this form of "being" in the world. Therefore, isolating it is not part of the ultimate analysis strategy. What is important to note is that, in the case in question, the Caipora's myth performs an operation that includes a past time and a present time. Even though the Caipora is no longer so easily found nowadays - due to the lower densification of the forests, according to local reports - it is enough "to go around in the woods to find it."

This "fantastic" form found during our fieldwork to narrate the important facts of social life reveals a quilombola territory that is latent there, despite the external pressures in the sense of its disarticulation. Even though the physical territory is now limited, due to the successive territorial loss and the spatial reconfigurations derived from the processes and advances of the larger owners, the mythical narrative helps to access that territory which is embodied in spaces through mythic action. The "times of the forest" and the "care" with nature: Therefore, it is worth mentioning that the "quilombola issue" suffered and still suffers the risk of retreat, both in the administrative arena and in the broader legal and political arena. In this sense, it is noted that such "mistrusts" and "insensities" described above, take, in the present moment, clear and objective contours. Thus, our argument here revolves around the notion of a narrative circularity between macro and micro politics. Mainly when such characteristics are appropriated and invigorated by the most conservative sectors of Brazilian society.

Beginning in 2015, a CPI (Parliamentary Commission of Inquiry) is created by lawmakers linked to agribusiness and representatives of the conservative sectors of the political staff, with the objective of ascertaining - among other things - the veracity of the identities of quilombolas and indigenous in Brazil. In this sense, the anthropological report becomes an object subject to the scrutiny of such parliamentarians of the CPI, usually suffering the accusation of being false or fraudulent. Among the arguments presented by the final report of this CPI, we find those who say that contemporary quilombos would not be composed of descendants of fugitive slaves, returning to a colonial definition of the notion of quilombo absolutely distant from that currently shared by quilombola groups, by the field of social anthropology. Today there are about 120 people indicted by the CPI, including anthropologists, public servants, religious and researchers.

\section{In bolivia}

Although separate in time for more than fifteen years, many parallels may be drawn when the constitutional demands for cultural and ethnic recognition in Brazil in 1988 are compared to the case of the Constitution of the Plurinational State of Bolivia, promulgated in 2009.

In Bolivia, the "multicultural"' policies of the 1990's-carried out

${ }^{2}$ Here we understand "multiculturalism", in the political-judicial sense, as an ideology based on a certain "cultural recognition" of other ethnic groups, inside a framework of a modern liberal democracy; and in the conceptual sense, as a philosophical perspective/worldview based on the supposed existence of "many representations (cultures) about the world", while there is only one world (which is "objectively" known through modern Science). ${ }^{24}$ This idea is opposed, in current anthropological debates, by a perspective known as "multinaturalism", as coined by Brazilian ethnologist Eduardo Viveiros de Castro (2002), according to which there would be "many worlds" instead of "many social representations about one world". by a right-leaning government with an indigenous vice-presidentalready showed the fact that indigenous groups would soon come to the foreground of Bolivian national politics. ${ }^{9}$ After a progressive intensification of the activities of the social movements (indigenous, syndicalist and indigenous, non-indigenous syndicalist, among others) throughout the decade, the 2000's began as one of the most intense periods of social, political and economic unrest in the recent history of the country. Marked by historical conflicts such as the Guerra del Agua (Water War) and the Guerra del Gas (Gas War), that period resulted in the election of Evo Morales, an ethnic Aymara rural trade union leader, as president of Bolivia in 2015. Such victory was made possible thanks to the power base provided by the indigenous and unionist social movements that formed the socalled Pacto de Unidad (Unity Pact, in English) ${ }^{23}$ thus the demands around which the alliance had been forged were promptly advanced among them, the Constituent Assembly, gathered in July 2006. ${ }^{8}$ The Assembly was a slow, tense process, marked most of the time by the intransigence of both the opposition, headed by the PODEMOS party and the government party (MAS) and its allies. From August 2006 to February 2007 the discussions were centered on the debates regulation, with the MAS in favor of simple majority $(50 \%+1)$ and PODEMOS defending a two-thirds (2/3) majority vote, which was, in the end, the final decision. ${ }^{25}$ During that same period, another part of the Assembly aimed at forming and distributing the 21 thematic commissions, which started functioning partially on January 2007. In mid-2007, nonetheless, a small conflict regarding the change of capital from La Paz to Sucre escalated and turned into a nationwide divide which froze the Constituent process for months, amidst violent protests in Sucre and other cities. ${ }^{9}$

Only in October 2008, after a ratification referendum that gave the MAS a $67.4 \%$ approval, was the opposition willing to recognize the final version of the Constitution and opening the referendum for ratification after reviewing the constitutional text. That is when the government, in detriment of its indigenous power base, gave most of the concessions which took away many of the social movements' propositions. Finally, in January 2009, the motion for the constitutional wins with $62 \%$ votes and in February the new Bolivian Constitution was promulgated with a historic ceremony in El Alto, an Aymara majority city near La Paz.

Throughout this whole process, the Unity Pact was an instance of coordination for the rural and/or indigenous social organizations from the East and West of Bolivia (the so-called lowlands from the Chaco and Amazonia and the Andean highlands, respectively). The Pact had been created with the aim to articulate the movements' action, first, for the implementation of the Constitutional Assembly and after its start, to discuss and promote the interests of peasants and indigenous peoples (among other social sectors) along the Assembly. ${ }^{23}$

That is where one of the fundamental differences among the Bolivian and Brazilian processes are found: while in Brazil, indigenous and quilombolas where largely mediated by other actors and albeit the considerable influence that the social movements formed by those groups had in the process, their participation had a rather indirect nature, with the inverse happening in Bolivia. The constitutional process there had a more direct action of the groups involved as the main driving force. The same was true for the content of the new text: despite the concessions that had to be made, it is remarkable that the "original project" of the Constitution for the government was the document created by the Unity Pact, containing proposals as radical as direct representation, bilingual intercultural education and legal recognition of indigenous medical knowledge. ${ }^{8}$ 
Even in the document's final version, the State assumed ideals of different indigenous cultures such as sumaqamaña (the Aymara concept of buenvivir), ñandereko (from the Guarani, harmonious life) and qhapajñan (noble path), among others as "ethical-moral principles of a plural society"(Article 8, I). Among these, the concept of buenvivir (or vivirbienas it is translated to Spanish from Aymara language, roughly translatable to English as "good living" or "living well") deserves particular attention, as it has been one of the key concepts in recent Indigenous politics in South America (as, for example, in Ecuador). Suma qamaña (vivirbien) combines the idea of material well-being with pacific social coexistence and mutual support and solidarity. ${ }^{26}$ The sumaqamiriis the person who "lives and coexists well, because he/she is welcomed by other and knows how to welcome others, as well as collaborate with what he/she has. It cannot happen individually, but in (and with) a social group". ${ }^{27}$ The sumaqamaña becomes, thus, a "meta-value" to which other values (like equality and inclusion) must be subjected. ${ }^{27}$ Even the education system (Art. 80, I, Ch. VI) and the proposed economic model (Art. 306, I, III, Ch. VI) appear as guided by the sumaqamaña principle.

Moreover, thirty-six indigenous ethnicities or nations that are part of the country were recognized and their languages made official. Thus, the radicalism that was present in the composition of the new Constitution (in spite of the strong opposition by more conservative sectors to reforms of this nature) remained evident until the final constitutional discourse. The critical power of such discourse is also found in later legislations (where many decisions were pushed to, during the Constituent Assembly), namely the Law of Mother Earth n. 71 and the Framework Law of Mother Earth and Integral Development for Vivir Bien n. 300, decreed on December 2010 and October 2012, respectively. Law n. 71 constituted the first legal declaration of the recognition of rights to Pachamama (the Andean entity known elsewhere as "Mother Earth" or "Gaia"), which, in Article n. 5 of its second chapter, states that "for the purposes of protecting its rights, Mother Earth gains the statute of a collective subject of public interest" and gives a list of a series of rights to which it is entitled to, such as the right to life and to existence; to the continuation of its cycles and vital processes, among others. ${ }^{28}$

The draft version of these laws is a cosmo-political manifesto ${ }^{11}$ that puts together Western and Indigenous concepts, creating remarkable intercultural dialogues. The Indigenous South-American imaginary is present in several moments of the text, starting with the Preamble, in which the origins of the Universe and of the Earth are described, mixing elements of modern Astrophysics and Cosmology with the Andean notions of such elements, defining Pachamama as "the conjunction of space-times and the cycle of these space-times; the cosmic space-time of the pluriverse; the present space-time, of place, territory, biodiversity; the interior space-time, of the entrails of the Earth and the bodies". ${ }^{10}$ Similarly, epistemic diversity appears as a central theme in the constitutional process. The Constitution ensures the right of Indigenous peoples "to have their traditional knowledge, their medicine, their language, their rituals and symbols valued, respected and promoted" and to the collective intellectual property of their knowledge and sciences, to its use, promotion and development". Concomitantly, Law n. 300 has, among its declared principles, the "dialogue between knowledge's", assuming the "complementarity between traditional knowledge and modern sciences", thus evidencing the centrality of epistemological pluralism in the Bolivian constitutional discourse.
The reflections we propose here relate to what Enrique Dussel ${ }^{29}$ calls transmodernity. Such concept indicates the eruption, from the relative exteriorities of the Modern world, of universal cultures in their own processes of development, which assume the challenges of Modernity and even the euro-american post-modernity, but respond to them from another place, the place of the Otherness. When looking at the indigenous concepts adopted by the Plurinational Constitution, what is met by these elements that "irrupt from the relative exteriorities of Modernity, questioning it and at the same time relating to it (i.e. Judicial elements from an oral culture in dialogue with a Modern, written, State Constitution) through the pursue of interculturality, which, going further than multiculturalism (based on mere recognition without tackling hierarchies), puts these different cultures in a political dialogue as symmetric as possible.

Notwithstanding the apparent advances, the years after the Constitution's promulgation had witnessed the rupture of the Unity Pact, marked by the cleavage between the two worldviews united beneath its name. On the one hand, the indigenous, with its propositions of radical decolonization of the State, direct representation by indigenous groups and territorial autonomy and on the other, the nacional-popular of the trade union movements, based on a popular nationalism oriented towards industrialization of the countries' natural resources and a classical developmentalist discourse of modernization. ${ }^{11,30}$ Already present since the discussions in the Assembly, the cleavage grew as the opposition no longer posed a threat to the continuity of the constituent process, but in 2011, with the tensions that became known as the TIPNIS Conflict (Indigenous Territory Isiboro Sécure National Park), the rupture became permanent. ${ }^{31}$ The conflict (which cannot be discussed here, given our limited space) happened with the opposition of the main indigenous movements and most of the population (though not its totality) that inhabit the TIPNIS, against to the construction of a highway that would cross the territory, promoted by the government and defended by the other part of the Unity Pact. Once again, in Latin America, the colonial structure was evident in the conflict between developmentalist government and indigenous peoples. ${ }^{32}$ This is another encounter point between the two cases analyzed here.

\section{Final considerations}

If, on the one hand, indigenous and Quilombola movements and their participation in the Constituent Assembly left their mark on Latin American history and politics through their influence on the pages of the respective Constitutions (with more or less radicalism, as we saw in two cases in perspective) on the other, colonial continuity forms the main barriers to epistemic (and political) decolonization at stake. While constitutional discourse is more easily pervaded by indigenous discourse, the postcolonial political structure does not allow such elements to enter so quickly.

In comparative terms, our work evidences the profound difference between the Brazilian and Bolivian cases towards a Latin American liberation movement. In spite of all the internal contradictions present in the two historical processes of liberation of the groups originating in Bolivia and Brazil, in the Bolivian case a broader movement can be seen in relation to the intercultural relations between the state and the indigenous groups. The categories used in the cases presented above show these different arrangements.

In the quilombola's case, which is analyzed here, we can see that 
the greater discrepancy between the categorical legal/administrative spectrum and the quilombola's set of experiences reveals risks that are not only contained in "aesthetics" or the whims of an anthropological report. Suspicious discourses can gain higher levels of structural organization, deriving, as we can see today, a possible loss of instituted constitutionally rights.

In the Bolivian case some indigenous notions are perceived as legally relevant categories (presenting a more radical operation from the point of view of transmodernity), in the Brazilian case (despite the advances of 1988), we are captured by a certain logic of a liberal multiculturalism. Therefore, recognition that reaches clear limits from the point of view of concrete dialogue. In Brazil the categories of recognition are based on notions of identity and the Bolivian experience reveals the bets on the cosmologies, in the modus vivendi and in the buenvivir of the indigenous Bolivian cultures. With different cultures being able to enter in a horizontal dialogue where both "worlds" recognize each other as political anagonists, an ontological pluralization of politics is called for ${ }^{33-40}$ and this is where the indigenous concepts newly included in the Bolivian Constitution appear as radical ${ }^{40-50}$ Therefore, although aware of the contradictions and internal limitations of each of these historical processes, we are betting here on the idea of a more radical decolonization in the Bolivian case. ${ }^{50-60}$

\section{Acknowledgments}

None.

\section{Conflict of interest}

Author declares that there is no conflict of interest.

\section{References}

1. Cantarino. Quilombos: tema e problema. Secretaria Maranhanse De Defesa Dos Direitos Humanos, Jamary dos Pretos: terra de mocambeiros, Brazil; 1998.

2. Enrique D. 1492: el encubrimiento del otro: hacia el origen del mito de la modernidad. Editorial Nueva Utopía, Spain; 1992.

3. Almeida AWB. Terras de preto, terras de santo, terras de índio-uso comum e conflito. In: Hábette J, Cstaro Edna, editors. Na trilha dos grandes projetos. Belém: NAEA/UFPA, 1989. p. 163-196.

4. Almeida AWB. Quilombos: sematologia face a novas identidades. Frexal: terra de preto, Quilombo reconhecido como reserva extrativista, Brazil; 1996. p. 11-19.

5. José ACG. O Território Da Linha Cruzada: Rua Mirim versus Avenida Nilo Peçanha-Porto Alegre (1992-93). Dissertação (Mestrado em Antropologia Social)-PPGAS, Universidade Federal do Rio Grande do Sul, Porto Alegre, Brazil; 1993.

6. Baptista SS. São Miguel e Rincão dos Martimianos. Territorialidade e ancestralidade negra, Porto Alegre, Brazil; 2004.

7. Macedo BD. O fantasma de Dona Branca: assombrações e ameaças num assentamento rural. Revista Barbarói. 2000;12:41-52.

8. Schavelzon S. El Pacto de Unidad como encuentro cosmopolítico. Revista Boliviana de Investigación. 2013;10:235-261.

9. Schavelzon S. El nacimiento del Estado Plurinacional de Bolivia: Etnografía de una Asamblea Constituyente. La Paz: CLACSO, PLURAL, IWGIA, CEJIS, Brazil; 2012.

10. Schavelzon S. As categorias abertas da nova Constituição boliviana Formação do Estado Plurinacional: alguns percursos intelectuais. Lugar Comum. 2011;27:35-59.
11. Isabelle S. The Cosmopolitical Proposal. In: Bruno L, Luis TM, editors. Política salvaje La Paz: CLACSO, Muela del Diablo, Comuna, Brazil; 2008.

12. Jorge CJ. O quilombo do Rio das Rãs. Histórias, tradições, lutas. Salvador, Brazil;1996.

13. Fátima CM. Reconhecimento de direitos face aos (des)dobramentos da história: um estudo antropológico sobre territórios de quilombos. Tese (Doutorado em AntropologiaSocial), Porto Alegre, Brazil; 2005.

14. Boaventura LI. Quilombos: cidadania ou folclorização? Horizontes Antropológicos Porto Alegre. 1999;5(10):123-149.

15. Boaventura LI. O legado do testamento: A comunidade de Casca em perícia. Porto Alegre. Brazil; 2003.

16. Cantarino OE. Terra de Quilombos. Rio de Janeiro, Brazil; 1995.

17. Santos GF. O "Campo negro" de Iguaçu: escravos, camponeses e mocambos no Rio de Janeiro (1812-1883). Revista Estudos AfroAsiático. Rio de Janeiro. 1993;25:43-72.

18. Pinho AO, Sansone L. Quilombos, Raça: novas perspectivas antropológicas. EDUFBA, Brazil; 2008. p. 1-449.

19. Jobi SC, Ubirajara T. Demonstrations and the Quilombola Cause: New Protests for Old Claims. Cultural Anthropology. 2013;1:1.

20. Jobi SC. A “janela” do relatório técnico: variabilidade, criatividade e reconhecimento social em contextos de perícia antropológica. Porto Alegre, Brazil; 2012.

21. Heraldo MR. Um aspecto da diversidade cultural do caboclo amazônico: a religião. Estudos Avançados. 2005;19(53).

22. Moira Z. Los movimientos sociales en el poder? El gobierno del MAS em Bolivia. Nueva Sociedad. Argentina; 2010. p. 227.

23. Eduardo VC. A Inconstância da alma selvagem e outros ensaios de antropologia. Mana; 2002;9(1).

24. Valeria CAI, Xavier A. Cronología de la Asamblea Constituyente, T'inkazos: Revista Boliviana de Ciencias Sociales. 2008;11(23-24).

25. Gregor BC. Nuevas narrativas constitucionales em Bolivia y Ecuador: el buen vivir y los derechos de la naturaleza. Latinoamérica; 2014;2(59):9-40.

26. Albó Xavier. Suma qamaña = el buen convivir. La Paz: Centro de Investigación del Campesinado, Bolivia mayo. 2009. p. 1-12.

27. John V. Bolivia enshrines natural world's rights with equal status for Mother Earth. The Guardian. 2011;10.

28. Enrique D. Transmodernidad e Interculturalidad: Interpretación de la Filosofía de la liberación. UNAM, México; 2005.

29. René Z. Lo nacional-popular em Bolivia. Siglo XXI. México; 1986. p. 355.

30. Manuel C, Ínigo E. El conflicto del TIPNIS y la disputa por lo indígena en Bolivia. In: Esther DC, editor. Interculturalidad, democracia y desarrollo em Bolivia. 2012. p. 236-251.

31. Fernando M. O discurso da natureza: ecologia e política na América Latina. Editora UFSC Bernúncia Editora, Brazil; 2012.

32. Marisol CD. Indigenous Cosmopolitics in the Andes: Conceptual Reflections beyond "Politics". Cultural Anthropology. 2010;25(2):334-370

33. Cantarino. Os quilombos e as novas etnias. Quilombos-identidade étnica e territorialidade. Rio de Janeiro FGV, Brazil; 2002. p. 1-4.

34. Terras Tradicionalmente Ocupadas: processos de territorialização e movimentos sociais. Revista de Estudos Urbanos e Regionais 2004;6(1):9-32. 
35. O tribunal dos tribunais: onde se julga àqueles que julgam raças. Horizontes Antropológicos. 2005;11.

36. Remanescentes de quilombos: reflexões epistemológicas. In: Boaventura I, editor. Laudos periciais antropológicos em debate. Nova Letra Gráfica e Editora, Florianopólis. 2005;1:89-112.

37. Arjun A. The past as a scarce resource. Man. 1982;16(2):201-219.

38. Andion AJM. A Emergência dos Remanescentes: Notas para o Diálogo entre Indígenas e Quilombolas. Mana; 1997;3(2):7-38.

39. Andion AJM. Agenciamentos políticos da 'mistura': identificação étnica e segmentação negro-indígena entre os Pankararu e os Xocó. Estudos Afro-asiáticos. 2002;23(2):211-395.

40. Andion AJM. Mocambo: Antropologia e história do processo de formação quilombola. Mana; 2006;15(2):370.

41. Lourdes BM. Território negro em espaço branco. Brasiliense. Brazil 1988. p. 1-2.

42. Fredrik B. A análise da cultura em sociedades complexas. O guru, o iniciador e outras variações antropológicas. Rio de Janeiro: contracapa. Brazil; 2000. p. 1-17.

43. Daisy B. Comunidade negra de Morro Alto. Historicidade, identidade e territorialidade, Porto Alegre, Brazil; 2004.

44. Bensa A. Da micro-história a uma antropologia crítica. In: Jacques $\mathrm{R}$, editors. Jogos de escalas: a experiência da microanálise. Rio de Janeiro FGV. Brazil; 1998.

45. Paula AC. O Espaço da Diferença no Brasil: etnografia de políticas públicas de reconhecimento territorial e cultural negro no sul do país. Doctoral Thesis in Social Anthropology. Universidade Federal do Rio Grande do Sul, Brazil; 2008.

46. Clifford G. A Interpretação das Culturas. Rio de Janeiro. Brazil; 1978.

47. Santos GF. Histórias de quilombolas: mocambos e comunidades de senzalas no Rio de Janeiro. Companhia das Letras, Brazil; 2006.

48. Gusmão. A dimensão política da cultura negro no campo: uma luta muitas lutas. Tese Doutorado em antropologia social, Brazil; 1990.
49. Boaventura LI. Laudos antropológicos em debate. Florianópolis: Nuer UFSC ABA, Brazil; 2005. p. 89-112.

50. Moura MM. Caminhos criativos da história. Territórios da memória em uma comunidade negra rural 2008 (Dissertação de mestrado). Universidade Estadual de Campinas, Brazil; 2008.

51. Staudt MPR. Os cativos e os homens de bem: experiências negras no espaço urbano. Porto Alegre, Brazil; 2003.

52. Cantarino OE. Quilombos. Identidade étnica e territorialidade. Rio de Janeiro. Brazil; 2002. p. 268.

53. Cantarino OE. Laudos Antropológicos: pesquisa aplicada ou exercício profissional da disciplina? In: Ilka LB, editor. Laudos antropológicos em debate, Nuer UFSC ABA, Brazil; 2005. p. 214-238.

54. Bronz D. O Papel Social do Antropólogo. A aplicação do fazer antropológico e do conhecimento disciplinar nos debates públicos do Brasil contemporâneo. Rio de Janeiro E-Papers. 2010. p. 130.

55. Oliveira FJ. Uma etnologia dos 'índios misturados'? Situação colonial, territorialização e fluxos culturais. MANA Estudo de Antropologia Social. 1998;4(1):47-77.

56. Plurinational State of Bolivia. Ley Marco $N^{0} 300$ de la Madre Tierra y Desarrollo Integral para Vivir Bien, Bolivia; 2012.

57. Plurinational State of Bolivia. Ley $\mathrm{N}^{0} 71$ de Derechos de la Madre Tierra, Bolivia; 2010

58. Constitución Política del Estado (CPE). Texto final compatibilizado. Asamblea Constituyente/Honorable Congreso Nacional, Bolivia; 2008.

59. Aníbal Q. La colonialidad del poder y la experiencia cultural latinoamericana. In: Roberto BL \& Heinz RS (Eds.), Pueblo, época y desarrollo: la sociología de América Latina, CENDES, LACSO, Nueva Sociedad, Caracas, Brazil, 1998. p. 201-246.

60. Peter W. Making Things Public. Atmospheres of Democracy. MIT Press, Cambridge; 2005. p. 994-1004 